Article

\title{
Towards Sustainable Neighborhoods: Challenges and Opportunities for Neighborhood Planning in Transitional Urban China
}

\author{
Qi Zhang*(D), Esther Hiu Kwan Yung and Edwin Hon Wan Chan
}

Building and Real Estate Department, The Hong Kong Polytechnic University, Hung Hom, Kowloon, Hong Kong 999077, China; esther.yung@polyu.edu.hk (E.H.K.Y.); bsedchan@polyu.edu.hk (E.H.W.C.)

* Correspondence: hbzq007@gmail.com; Tel.: +85-255-192-075

Received: 21 December 2017; Accepted: 31 January 2018; Published: 4 February 2018

\begin{abstract}
Unlike many developed countries where sustainable development has been implemented at neighborhood scale, sustainable planning research and action has still been concentrated at the national level and little has focused on the neighborhood level in China. This issue was highlighted by the demand of facilitating sustainable development and significant transition of the socio-political context, which made the development of neighborhood planning even more urgent and challenging. Hence, this study aims to identify the major challenges, particularly related to the institutional aspects, for adopting neighborhood planning in the local community in China. Comprehensive literature review was employed to demonstrate the crucial position of institutional elements in facilitating sustainable neighborhood development and planning. A comparative study of the common characteristics for adopting neighborhood planning in four different countries was conducted. Based on the characters, the possible barriers hindering the practice of neighborhood planning in China were proposed and then validated with the in-depth expert interviews. The results show that there is little support from national policy and local governance, ambiguous legislation on community public management, as well as inadequate public participation and a weak sense of community. Corresponding policy implications and recommendations are included to provide insight for planners and decision makers to better utilize neighborhood planning to achieve sustainable urban development.
\end{abstract}

Keywords: sustainable; neighborhood; planning; transitional; urban; China

\section{Introduction}

Sustainable development has been the subject of political, professional and academic discussion for more than 20 years. Basically, it aims to balance the effects of overall development in terms of three dimensions: environment, economic and social. The initial focus of this three-pillar concept, according to Agenda 21 [1], was on the national level. However, the challenges of implementing sustainable development are more often revealed at the local level, including cities and towns [2]. Therefore, planning and development decisions at local level gradually play a significant role on enhancing the local sustainability [3,4]. In response to this concern politically, several thousand municipalities in different countries adopted the 28th chapter of Agenda 21, often known as "Local Agenda 21," which triggered the action at local scale [5]. In the past two decades, the Local Agenda 21 has evolved with specific historical context and consequently some of it are still active today while some had died out. To provide updated guidelines, new global commitments and standards of sustainable development, including 2030 Agenda and New Urban Agenda, had been adopted by world leaders in 2016 and the sustainable cities and neighborhoods were both under the spotlights [6]. 
Neighborhoods planning is arguably important when facilitating sustainable development at the local level. As major spaces where human activities occur, a city is considered sustainable only if its components, particularly neighborhoods and building environment, meet the sustainability criteria [7]. As basic planning units, neighborhoods have always been of particular interest to urban planners [8]. Accordingly, an increasing number of new initiatives for neighborhood planning has been developed to cope with local sustainable issues in not only advanced countries but also several developing countries like Malaysia and Qatar [9-11]. Comparatively, neighborhood planning in China is still at its infancy.

Although few studies on neighborhood planning and sustainable neighborhoods are available from recent years [12-15], both the theoretical and practical development of sustainable neighborhood planning is still at the exploratory stage in China. It started recently drawing more attention as the expanding sustainability challenges in transitional China. In this world's largest developing country, cities experienced triple transitions of marketization, decentralization and globalization and these three drove the urbanization and urban plan expansion [16]. Urban neighborhoods, as the basic unit of residential area of city, have also experienced significant transitions from the work unit (danwei) era to the commodity housing era since the housing reform in the 1990s [17]. This transition has paralleled rapid urbanization rate from $20 \%$ in 1980 to $56.1 \%$ in 2015 . The year of 2011 was a milestone of China urbanization history when the people living in cities became more than those living in countryside [18]. Under these significant transitions, sustainable challenges, such as declining social capital, urban sprawl, traffic congestion, environmental deterioration, declining urban culture, land overdevelopment and social inequality, etc., have put neighborhood sustainability issues in the spotlight.

To develop sustainable neighborhoods in China, identifying the major obstacles that hinder neighborhood planning development becomes more significant and urgent. Particularly, the strong association between policies, urban planning and sustainable development in China [19] highlighted the significant effect of institutional elements. Theoretically, decentralization and community empowerment, public participation, cultivation of community sense, iterative and adaptive planning etc. were the four main aspects in which neighborhood sustainability can be affected institutionally. But these aspects may vary from country to country because of different local context. In China, the neighborhood governance is obviously different from that in Western Countries in terms of organizations and structure, participation in the residential planning, degree of autonomy, social service delivery, community sense, historical ideology etc. Therefore, it is necessary to identify, validate and supplement the institutional aspects in the specific context of China that contribute to the sustainable neighborhood planning.

Thus, this study mainly focuses on institutional aspects which largely affect the practice of neighborhood planning in transitional China. It relies on an extensive review of the literature on neighborhood planning, sustainability and relevant practices to gain an understanding of the common characteristics of neighborhood planning practiced in different countries. Particularly, China literature was analyzed to identify potential barriers to fulfilling common characteristics of neighborhood planning shared by other countries in China. This is followed by in-depth interviews with experts to further validate and elaborate on the barriers and challenges that hinder the development of neighborhood planning. Some policy implications and recommendations are also provided in this paper.

\section{Background Theory}

The global concerns about sustainable development at neighborhood level were reflected in a wide range of academic works. The pioneer scholar, Jane Jacobs, clearly stated that a sustainable way of living should effortlessly derive from the way we design our sustainable neighborhoods, as they are beneficial to the community and the individual, as well as the environment [20]. Berardi [21] recognized that neighborhood was the minimum scale to consider social sustainability and the assessment of sustainability of neighborhoods needs to consider the ways in which economic, environmental and social level are related to the citizens. 
Other than the traditional three-pillar concept, institutional sustainability gradually turned to be the fourth dimension when substantial implementation advocated by Agenda 21 were expected [22]. This trend implies the institutional role of neighborhood planning as a local method to enhance neighborhood sustainability. Particularly, in China, the fourth pillar of sustainability was locally challenged since a comprehensive transformation of neighborhood governance occurred. The switch of local governance from danwei compound system to community-shequ organization created an interesting context: A modern effective pattern of neighborhood governance was expected and meanwhile, a unique China-based opportunity to promote neighborhood sustainability through neighborhood planning was historically provided [12].

\subsection{Neighborhood Concept and Neighborhood Planning}

The term 'neighborhood' describes a well-known concept in the history of the development of urbanization. There are a number of commonly used definitions of 'neighborhood' such as "a geographically localized community located within a larger city or suburb" or "a separately identifiable area within a community retaining some quality or character which distinguishes it from other areas" or "an area where the residents are drawn and held together by common and beneficial interests" [7]. The concept of neighborhoods has been a constant topic of investigative interest for historians, sociologists and urban planners since the late 19th century.

From the urban planning perspective, urban managers started designing and developing livable and eco-friendly neighborhoods from the early 20th century when Ebenezer Howard's Garden City movement was proposed. But it was not until 1929, when Clarence Arthur Perry proposed the 'neighborhood unit concept,' that planning on a neighborhood scale was formally considered by professionals in residential planning process [8]. He integrated neighborhoods into urban planning activities and defined an ideal neighborhood that would "embrace all the public facilities and conditions required by the average family for its comfort and proper development within the vicinity of its dwelling" [23] (p. 50). Since then, neighborhood-based planning has gradually attracted planners' interests and comprehensively developed in both the industry and academia. In addition to physical planning, citizen participation and social interaction were also primary concerns when a neighborhood was planned [7]. Many scholars argue that neighborhoods are the most recognizable and viable units of identity and it is on this level that actions should be taken to customize planning alternatives [24,25].

Although neighborhood became an important unit for urban planning, it is still challenging to precisely define, especially the scale of a neighborhood. It was found that the scale varied from a social unit, a spatial unit or a network of relationships and the associations and patterns of uses [26]. Park and Rogers also identified the difficulties of selecting the right scale of neighborhood through a review of planning theory, guideline and empirical research [27]. This issue became even more challenging in the China context due to the long term and specific socio-political evolvement. A plethora of neighborhood form had been derived during the transition from centrally planned to a more market-driven economy in China [28]. These types include work unity compound, commodity housing estates and autonomous communities etc. with different building density and population size due to local context. Particularly, the average population of a neighborhood in China is much higher than that in the advanced Western countries since China owns the largest population across the world but limited livable land area. Therefore, the neighborhood population size is relatively higher than that in Western countries. Given the above issues, defining the scale of the neighborhood and comparing the population difference between China and the West is not the focus of this paper.

\subsection{Institutional Aspects of Neighborhood Planning to Achieve Neighborhood Sustainability}

Recently, neighborhood planning has been increasingly promoted as a tool to enhance local sustainability, especially in developed countries. Taking the preparation of neighborhood plan in UK as an example. Town or parish council is responsible for the neighborhood plan and to engage public stakeholders into the planning process. Local planning authority must take decisions at key stages in 
the neighborhood planning process within the time limits that apply and provide advice or assistance to a parish council in producing the plan. Specifically, how neighborhood planning is prepared and links with neighborhood sustainability is demonstrated in the Table 1 below.

Table 1. UK example: How neighborhood plan is prepared and links with neighborhood sustainability. Source: How to prepare a Neighborhood Plan [29].

\begin{tabular}{|c|c|c|}
\hline The Order of Steps & $\begin{array}{l}\text { Eight Steps to Prepare a } \\
\text { Neighborhood Plan }\end{array}$ & Links with Sustainability Appraisal \\
\hline 1 & Getting started & \\
\hline 2 & Identify the issues & $\begin{array}{l}\text { Identify key economic, social and } \\
\text { environmental issues. }\end{array}$ \\
\hline 3 & Develop a vision and objectives & $\begin{array}{l}\text { Identify key national planning framework and } \\
\text { local planning objectives } \\
\text { Develop the sustainability framework } \\
\text { (objectives and criteria) }\end{array}$ \\
\hline 4 & Generate options & $\begin{array}{l}\text { Appraise the options using the } \\
\text { sustainability framework }\end{array}$ \\
\hline 5 & Draft your neighborhood plan & $\begin{array}{l}\text { Appraise the draft policies using the } \\
\text { sustainability framework }\end{array}$ \\
\hline 6 & Consultation and submission & Prepare the sustainability appraisal report \\
\hline 7 & Independent examination & \\
\hline 8 & Referendum and adoption & \\
\hline
\end{tabular}

By reviewing the planning procedures in UK as well as other countries, institutional aspects were found to be one of the fundamental factors contributing to the overall neighborhood sustainability. Among all the aspects, several critical elements' link with sustainability are identified and explained below:

\section{Decentralization and Community Empowerment}

Politically, neighborhood planning has been practiced as a method of planning devolution, which refers to the transferring or delegation of planning power to a lower level, to empower local communities under national decentralization policies in many countries, such as the UK, the US, Canada, etc. [30-32]. After researching forty European cities, Evans et al. [33] suggested that local governments were more proactive and adventurous in their policy-making and implementation regarding sustainability challenges when they were given higher degree of autonomy. The governments of several developing countries have also practiced decentralization of decision making in the past two decades, achieving effective sustainable development of community resources, social capital development, resource management and service provision at the local level [34,35].

For local communities, it is suggested that there is a direct relationship between decentralization and community empowerment and the latter is regarded as a tool to enhance local community capacities and assets [36]. Tan and Zhou [37] stated that decentralization increasingly attracted the attention of Chinese policy makers and researchers. Currently, the democracy and autonomy are placed at the center of the neighborhood (Shequ) concept in China. Thus, neighborhood planning, as one of the derivatives of decentralization, can lay a powerful foundation for activating local autonomy so as to institutionally promote the sustainable neighborhood development. 


\section{Public Participation and Decision Making}

Participatory planning and decision making which includes public participation and expert-based approaches, is advocated by many studies to promote sustainability [38,39]. Conventionally, sustainable development decisions have been mainly made by responsible authorities based on a group of indicators proposed by authoritative experts or international and national agencies. The local public had been consulted but its impact on eventual decision was very limited. Thus, the drafted policy or decision might not thoroughly reflect the local situations and well capture the local important factors. This turned to be a barrier hindering the local sustainable development. The basic sustainability conditions provided by general guidelines should be necessarily met but meanwhile the extra local characters should not be set aside. Thus, a new method to overcome sustainability challenges has emerged. It is argued that getting local input by engaging local citizen is of paramount importance to safeguard the representation and accuracy of the indicators and meanwhile help empowering the local community which conventional approach failed to do [40,41].

To get representative and reliable local input, neighborhood—size public meetings can be activated through neighborhood planning (step 3 and 6 in Table 1) for broader participation. Vulnerable groups, whose voice had been often ignored before, were concerned and encouraged to participate in neighborhood planning process. This inter-related process between neighborhood planning and social inclusion also implied the former's contribution to greater equity, particularly the equity of public resource use. In this sense, neighborhood planning can enhance social democracy, equity, inclusion and other sustainability dimensions by engaging neighborhood residents and fostering bottoms-up into the planning and decision-making process. Some scholars also argue that successful sustainability policies built on contextual features empower the residents of neighborhoods and help preventing simple top-down implementation [42,43]. Generally, local authority can make a more adaptive decision favoring sustainable development only if effective local inputs were obtained during the decision-making process.

\section{Cultivation of Community Sense}

Neighborhoods are referred to as collective spaces. The inhabitants and their sense of community and social capital play a dominant role in actively nurturing a sustainable neighborhood. The literature generally agrees that a strong "sense of community (SoC)" implies a healthy community and exhibits an extra-individual quality of emotional interconnectedness observed in collective lives [44] (p. 6). Some scholars also note that $\mathrm{SoC}$ is beneficial for the improvement of quality of life and social well-being, as well as life satisfaction [45,46]. All these major elements contribute to social sustainability. Since the inhabitants of a neighborhood are the focus of neighborhood planning, their sense of community should be cultivated through collective action at the issued identification, vision developing and other consultation stage and the social sustainability of the neighborhood can be enhanced.

\section{Iterative and Adaptive Planning}

For planning procedure, the iterative character is regarded as an institutional arrangement to safeguard that the drafted neighborhood plan meet the principles set by higher-level guideline or framework. In fact, the preparation of neighborhood plan is meant to follow a simplified version of the process used to develop a Local Plan. The development and appraisal of proposals in Local Plan documents should be an iterative process during which the proposals can be revised according to appraisal findings. The iterative process should inform the selection, refinement and publication of the preferred approach for consultation. For neighborhood plan, the iterative procedure would probably be time consuming but beneficial to largely ensure that the development proposal does meet the sustainability principles. 
For issues identification and solution option (step 2 and 4 in Table 1), an iterative and adaptive planning process is crucial for understanding urban challenges and adjusting neighborhood development plans to respond to both key internal and external factors. In a transitional world, urban planning is significantly challenged by the uncertainty of the future [47]. To cope with uncertainties and unprecedented changes of urban development, generating reliable knowledge and creating more predictable systems by command and control management is a common approach [48]. But, recently, this traditional approach did not work well enough in European countries and more engaged and bottoms-up planning forms were encouraged to diversify the planning methods in handling more complicated issues. In this sense, iterative planning can provide a regular and adaptive tunnel through which different stakeholders may get involved into local decision-making process. Thus, the iterative manner of neighborhood planning is considered better for enhancing neighborhood's capacity for surviving, adapting and growing in a transitional context so that sustainability problems brought by future uncertainties and complexities can be scientifically resolved. Marique and Reiter [49] also stated that testing and subsequently improving innovations, as well as reproducing current ideas through 'trial and error,' is required to foster sustainable neighborhoods.

\section{The China Context}

The big picture in which urban neighborhood evolved in China is generally transitional. Emerging sustainability challenges had gradually pushed the switch of governmental strategy from economic growth-oriented to balancing economic, social and environmental aspects in urban development. 'Sustainable development' was adopted as a national strategy in 1998 and the central government issued its first official 'National Report on Sustainable Development Report' in 2012 [50]. It is obvious that China is one of the most active countries which experiment sustainable urban development at national level by adopting diverse governmental policies and manners, including urban planning. However, the critical local level sustainability and planning strategies have still not been effectively addressed [51]. Among all the obstacles, institutional elements, particularly, are the outstanding ones.

\subsection{Emerging Urban Sustainability Challenges and Measures}

As negative effects of rapid urbanization, shortage of land, energy constrains and increasing population etc. are challenging the urban development in China. Cutting greenhouse gas emission and optimizing energy efficiency should be implemented since Chinese central government committed to reducing its carbon dioxide emission intensity by $40-45 \%$ by 2020 from the baseline of 2005 . Improving the poor air quality and inadequate green space in mega cities is urgent to improve threatened human health and urban livability. Rebuilding the weakened social connection, identity and capital during the process of urban neighborhood transition is crucial. The social justice between old inhabitants and new immigrants in terms of social welfare, job opportunity etc. should not be ignored either. Generally, the largest developing country should achieve a balance between GDP growth, social justice and environmental protection if a sustainable and steady development is expected.

To cope with these challenges, both top-down and bottoms-up measures had been practiced and tested. Different departments engaged in promoting sustainable development at national level, which mainly include Ministry of Housing and Urbane Rural Development, Ministry of Environmental Protection the National Development and Reform Commission. Various concepts of urban development were proposed by these departments, such as 'green city,' 'garden city,' 'Eco-city,' 'low-carbon city' to 'Eco-low-carbon city.' The focus of these concepts vary since different department has its own responsibility. However, these guidelines were relatively comprehensive and not necessarily specific so that clear visions and authoritative standard for implementation were deficient. Moreover, the marketing and frequent evolvement of these guideline policies were criticized for confusing both the researchers and public [51]. 
Regarding the local and neighborhood level, nationwide 'Community building' policies had been launched to promote sustainable development and remodel the old neighborhood governance (danwei) institutions since 1990s. Recently, 'Building Sustainable Neighborhoods' was a pilot project practiced in Chengdu, Sichuan province to rebuild a sustainable and resilient neighborhood, which was led by the Municipal Civil Affairs Department. Generally, the local development concerning sustainability becomes more comprehensive and different stakeholders were encouraged to take collective action in China. But there is still a lack of actual and broad participation on local level and by civil society.

\subsection{Major Urban Planning Issues Concerning Sustainable Development and Neighborhood}

For academia, in the past twenty years (1998-2017), the critical association between urban planning and sustainable development were manifested in the Chinese scholarly publications, as shown in Figure 1. The bar charts, which stand for the quantity of publications, rank the total publications containing specific key words below in the past twenty years. It implies the outstanding position of 'sustainable development' when urban planning researches were conducted in China. The database used here is CNKI (China National Knowledge Infrastructure) which is the leading national knowledge database in China.

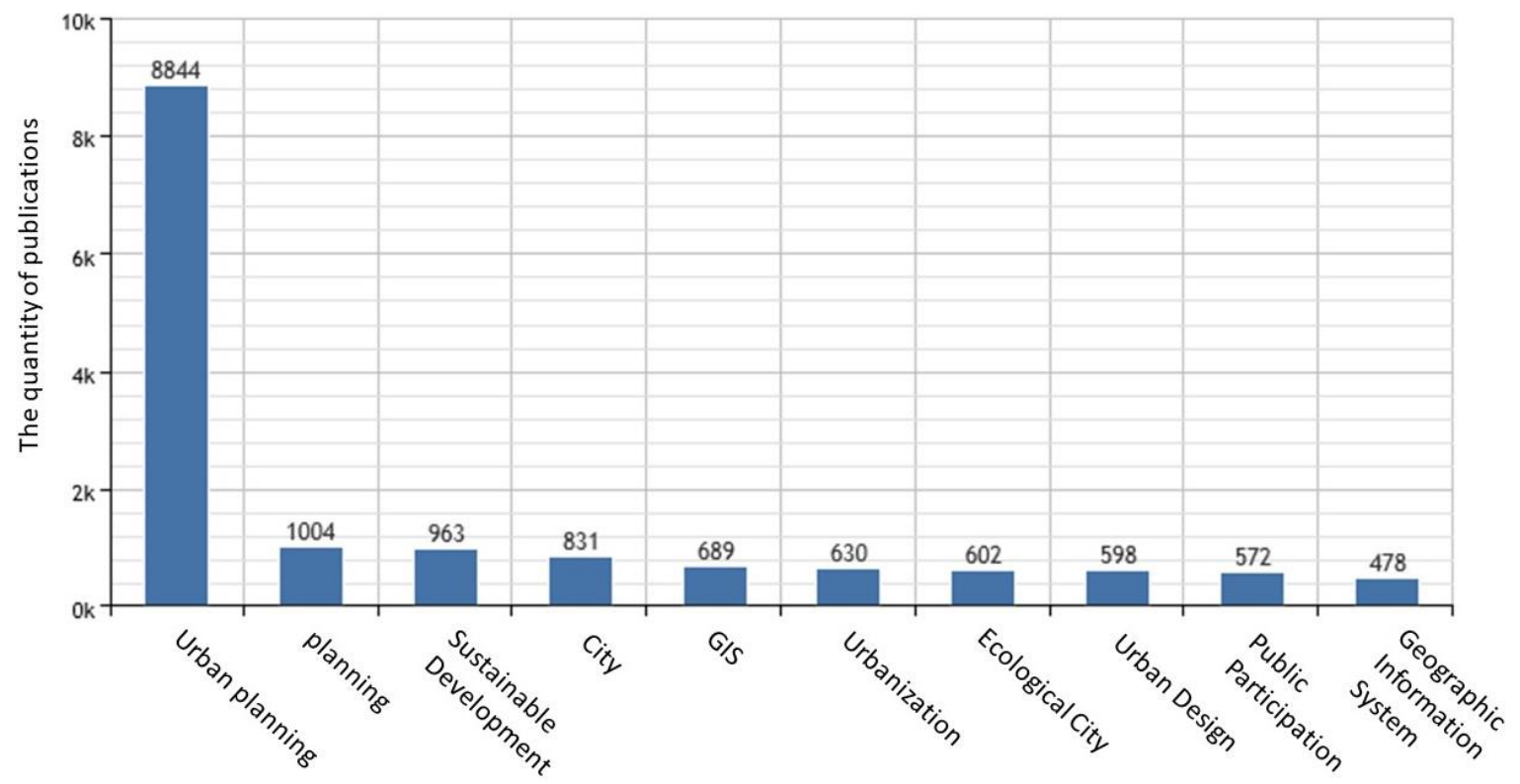

Figure 1. The ranking of publication quantity with different key words after searching 'Urban Planning' in CNKI database.

In practice, the vision and task of urban planning has been extended to respond to the updated requirement of sustainable development. The promotion of recycling economy industry, environmental-friendly lifestyle, ecological principles were emphasized in the planning practice recently. Planner are also required to understand the complicated link between urban challenges, scientific technology and human behavior to find a more holistic pathway to push the urban development into sustainable. Among all the challenges, a critical one is the absence of the substantial quantitative criteria or standard city of sustainable concept based on which planner can work out an appropriate and adaptive development plan.

Regarding the position of neighborhood in planning system, two major issues are identified as follows. They highlighted the trend and challenges that may affect the interaction between urban planning and sustainable neighborhoods.

Firstly, the link between the statutory plans and existing neighborhood plans in addressing local issues in China is lacking. The planning system in China consists of three major types of statutory plans: 
the general land use plan, urban master plan and the national economic and social development plan. All these plans mainly focus on construction activities in physical space and are unable to effectively incorporate social and other non-physical planning considerations [12]. Neighborhood accommodates most social activities but neighborhood planning has not yet been included in China planning system. On the other hand, existing community-based planning was very policy-oriented and can barely fit into the framework of statutory planning [52] (p. 5). This situation was paralleled by the present administrative elements that the responsible body for neighborhood-based planning is the Civil Affairs Department (CAD), rather than Planning Department (PD) [53]. For instance, the previous 'Constructive Planning of Community Service System' and relevant research on neighborhoods were initiated by the Civil Affairs Department without the Planning Department's participation.

Secondly, how public participation can better be institutionally and effectively executed was yet to be explored although 'public participation' was a statutory procedure of urban planning in China. As the enactment of the Urban and Rural Planning Law in 2007, legal status has been firstly given to the public participation in urban planning. It stipulates that the public shall be given the opportunity to participate in planning formulation before the plans are submitted for approval. However, there is still no law specializing public participation in China [54]. The absence of specialized laws and institutions has been criticized for leading to little constructive communication and discussions during the public participation process [55]. This highlighted the necessity of promoting neighborhood planning as a participatory, iterative and adaptive procedure to engage public stakeholders. Planning participation can be comprehensively organized at neighborhood level to improve the participation coverage and representativeness.

\subsection{Neighborhood Transition and Governance in Contemporary China}

\subsubsection{The Danwei Compound and Its Dissolution (1950s-1980s)}

Prior to the late 1970s, land use rights were strictly controlled by the state government and the pace of urbanization was relatively slow compared with that of Western countries. During this pre-reform era, the danwei compound (work unit), as a sign of a centrally controlled and planned economy, had played a significant role in China's local housing and governing system. It was a crucial tool used by the state to control society and to distribute resources [56]. Most of the urban residents had been designated into different 'danwei' compound which is a multifunctional institution. Social production, service, securities and management are the main functions that 'danwei' performs at then. The affiliated residents heavily relied on danwei for political participation and social welfare and security [57]. Normally, people spent most of their time living and working within this integrated space and the management order was maintained by a top-down authoritarian and planned system. Thus, the danwei system was accused of leading to a high residents' dependency on danwei in social activities and low social efficiency.

The turning point occurred in 1978 when national leaders made the strategic decision of "Reform and Opening Up" policy. China's fundamental economic institution started transforming from a central-controlled planned system to a market-oriented system and decentralization had been practiced as a part of the institutional reform. Thereafter, the danwei compound had been gradually dissolved, which was also regarded as a form of decentralization that governments started pulling out of neighborhood administration and granting more autonomy to the community grassroots. Meanwhile, the dissolution of danwei system promoted labor mobility throughout the whole country and neighborhood heterogeneity was consequently increased.

However, a new modern and effective system of grassroots regime has not yet been formally established while the old one started dissolving. The above socio-spatial change brought about major challenges to neighborhood governance. The higher degree of local autonomy brought by decentralization is not enough to build up a new efficient governance model. Meanwhile, the government faced the social risk which may lead to a disordered and discrete society due 
to the crash of old governance model. In addition to the growing number of urban population, Ma and $\mathrm{Li}$ [57] state that one of the specific challenges was the disruption of organizational bases for providing social services.

\subsection{2. 'Community Building' and the Local Governance (1990s-Present)}

To cope with the above challenges, the 'Community Building' policy was launched throughout the nation in the early 1990s [58] and it has been implemented for over 20 years. It acted as a crucial political tool for forming a social institution which has taken over welfare functions previously performed by the 'danwei.' Consequently, the 'neighborhood (shequ)' is now designated as the basic unit of social, political and administrative organization in urban China. Diverse spatially defined and territorially bounded 'shequ' have been established as a type of city zoning [59]. The municipal governments have delegated comprehensive functions to 'shequ' and the latter has rapidly developed in structure and function following the Central Government's instruction to 'strengthen grassroots regime construction' [60]. The urban local governance structure has become a multi-layer system consisting of the governments and autonomous organization as shown in Figure 2. The governments include municipal governments at the top, district government in the middle, street office at the bottom while the autonomous organization mainly refers to Community Residents' Committee (CRC).

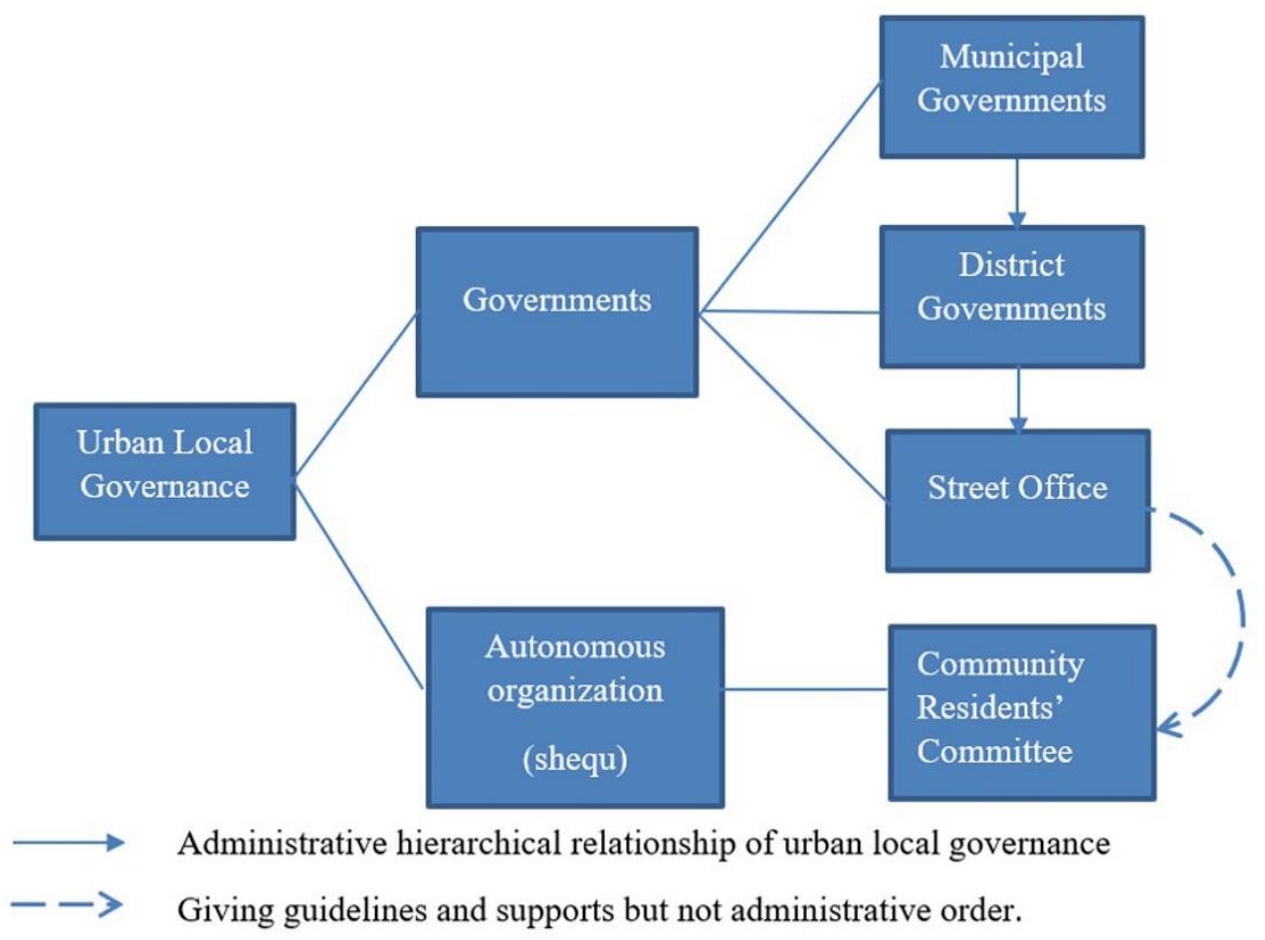

Figure 2. The structure and hierarchy of urban local governance.

Institutionally, for the 'shequ' system itself, it is an autonomous organization in which the Community Residents' Committee is the management center of autonomy. The shequ is responsible for providing almost all the administrative and civil service, including housing, property service, training, religious issue, health insurance, social security and environmental protection etc., to the all involved residents. CRC generally oversee the comprehensive development of shequ and it also acts as a conjunctive tunnel through which street office can communicate and interact with shequ residents. Apparently, the role of shequ in implementing governmental policies at lowest local level and getting feedback is irreplaceable within the local governance structure. Politically, although shequ is named as an autonomous organization and mainly accountable to the shequ residents, the operation of CRC was largely affected by the street office, especially financial and human resource issues (as the 
dashed line in Figure 2). This institutional arrangement and somehow bureaucratization is criticized for hindering the shequ autonomy. Given its comprehensive responsibility and authorities in economic, environmental and social area of shequ activities, CRC should be a crucial and unique subject in neighborhood planning if sustainable neighborhood development is expected in China.

\subsection{The Prominence of Institutional Elements in Sustainable Neighborhood Planning in China}

It is widely recognized that the political and institutional aspects are more prominent in the China urban planning system. Gu and $\mathrm{Hu}$ [61] categorized China's urban planning transition into four stages: Socialist master planning and anti-planning (1949-1978), reforming master planning (1979-late 1980s), urban development planning (early 1990s-2000) and comprehensive planning (2001-present). Particularly, they demonstrated that strong authority was still the major characteristic of urban plan making, implementation as well as the construction of large infrastructure and public facilities in China after these series of planning evolution.

It also can be identified that the promotion and facilitation of sustainable urban development was very policy-oriented at different level of Chinese governments. From 1970s to 2010s, 'green city,' 'garden city,' 'Eco-city,' 'low-carbon city' to 'Eco-low-carbon city' were successively proposed as political guideline for urban development [51]. The development of all these concepts is a constant and dynamic procedure that a new concept was derived from an old one with revision to adapt to new context. Three major methods used by government to promote sustainable cities were also categories by Liu [51]: Construction demonstrative models for nationwide replication; Building up awarding and incentive system to encourage local governments following proposed standards and criteria; Promotion of general objectives but allowing different local approaches to be adopted for reaching them.

Thus, by reviewing the China context above, the prominence of institutional and political elements in either neighborhood governance, urban planning system or sustainable development reveals its dominant and conjunctive role in facilitating sustainable neighborhood planning in China. For urban planning, strong policy oriented is conventional and legalization, particularly public participation, were gradually enhanced. Regarding neighborhood governance, financial and human resource and accountability of the actual governing pattern still play as an extension of local governments rather than higher degree of autonomy. For sustainable development, the content of sustainable guidelines had also been constantly affected by China's international commitment reacting to the global action advocates other than domestic evolvements. Theoretically, the sustainable neighborhood planning located within the overlapped area between these three and their relationships can be illustrated in Figure 3. Given the common character of institutional dominance between the three realms, the significance of firstly identifying institutional barriers to practicing neighborhood planning in this study was highlighted.

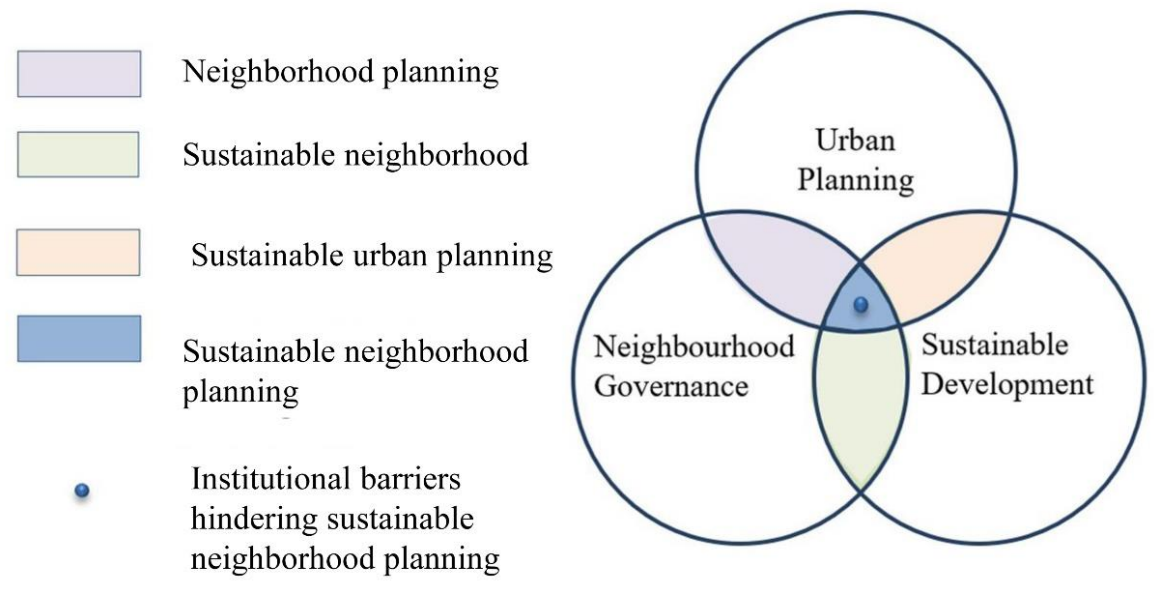

Figure 3. The relationships between different realms. 


\section{Methods}

This study began with an intensive review of professional journals, books, conference papers, governmental reports, newspapers, local publications, internet resources, etc., to critically analyze the theoretical background of neighborhood sustainability and planning. The institutional aspects of neighborhood planning, which contribute to the neighborhood sustainability, were summarized. A comparison study was then employed to identify common characteristics, based on the summarized institutional aspects, of neighborhood planning shared by other countries. Next, these characters were analyzed and transformed into potential barriers in China practice by the authors. Lastly, in-depth experts interview was adopted to further validate and supplement the potential barriers hindering neighborhood planning practices in China. The expert interview has become very popular as a "streamlined" method and it appears to be "quick, easy and safe" in its application and it promises to be of good practical value [62].

\subsection{Comparative Study of Neighborhood Planning in Four Countries}

The literature review of various sources provides information for the comparison of four different advanced countries/districts, namely the UK, the US, Canada and Taiwan and helps identify the common characteristics of neighborhood planning. Since the institutional aspects are the focus of this research (Section 3), these four countries were compared based on the summarized institutional aspects in Section 2.2 to identify those characters of neighborhood planning institutionally contributing to neighborhood sustainability.

The reason for selecting these four countries/districts is that the UK, the US and Canada are pioneers in successfully and comprehensively practicing neighborhood planning, while though Taiwan is culturally and geographically extremely close to China, the nationwide 'community building' movements there have been effective as well.

The key profile of these four countries were shown in Table 2 for understanding the general neighborhood planning practice and provided reference for demonstrating the comparability between them and China. The similarities between different countries, especially between the Western countries with Taiwan, provide useful lessons for neighborhood planning in China. 
Table 2. Key profile of the four containers where neighborhood planning has been practiced.

\begin{tabular}{|c|c|c|c|c|}
\hline Comparision of Aspect & UK & US & Canada & Taiwan \\
\hline $\begin{array}{c}\text { Urbanization Rate } \\
\text { (By urban population in 2016) }\end{array}$ & $80.8 \%$ & $83.2 \%$ & $81.9 \%$ & $77 \%$ \\
\hline Is NP a legal planning? & Yes & No & No & No \\
\hline Is the form of NP diverse or normative? & Normative & Diverse & Diverse & Diverse \\
\hline $\begin{array}{l}\text { What is the Status of NP in the Local } \\
\text { Development? }\end{array}$ & $\begin{array}{l}\text { The adopted plan becomes a part of } \\
\text { statutory development plan }\end{array}$ & $\begin{array}{l}\text { It varies from state to state. In a few } \\
\text { states, an adopted plan become a } \\
\text { component of city's development plan. }\end{array}$ & $\begin{array}{l}\text { The adopted plan becomes an official } \\
\text { guideline for neighborhood development }\end{array}$ & $\begin{array}{l}\text { An official scheme to engage public } \\
\text { into neighborhood development. }\end{array}$ \\
\hline $\begin{array}{l}\text { Which Local Body is Responsible for the } \\
\text { NP Projects? }\end{array}$ & $\begin{array}{l}\text { Parish or town council; } \\
\text { or Neighborhood forum; } \\
\text { or Community organization }\end{array}$ & City council & City council & $\begin{array}{l}\text { Community Empowerment Network } \\
\text { (Founded by Municipal Government) }\end{array}$ \\
\hline $\begin{array}{l}\text { Applied Neighborhood Sustainability } \\
\text { Assessment Tools }\end{array}$ & $\begin{array}{l}\text { 1. BREEAM Communities } \\
\text { 2. SPeAR } \\
\text { 3. OPL }\end{array}$ & $\begin{array}{l}\text { 1. LEED-ND } \\
\text { 2. ECC } \\
\text { 3. EPAT } \\
\text { 4. CS }\end{array}$ & $\begin{array}{l}\text { 1. FSA Tool } \\
\text { 2. SCORE Tool }\end{array}$ & EEWH-EC \\
\hline
\end{tabular}

Source: Sharifi and Murayama [10]; Bird [63]; Planning Practice Guidance [64]; Seattle Department of Neighborhoods [65]; A Guide for Developing Neighborhood Plans [66]; Community Empowerment Network, Taipei [67]; Worldometers, http:/ /www.worldometers.info/population/ [68]. 


\subsection{Expert Interview}

A panel of twelve experts was interviewed during September 2016 to October 2017 to discuss the relevance of common worldwide neighborhood planning characteristics in the context of China and to validate the proposed obstacles, which may hinder the development of neighborhood planning in China. The experts chosen were academics, professionals, governors and an NGO representative who have at least fifteen years of working experience in the field of urban planning, community governance and sustainable development in China. A profile of the experts' panel is given in Table 3. During the interviews, they were also presented with the barriers identified and asked to indicate their agreement with each, respectively. They were also asked to supplement any barriers if any.

Table 3. Profile of the experts' panel.

\begin{tabular}{|c|c|c|c|}
\hline Expert & Name & Field of expertise & Affiliation \\
\hline 1 & Mr AA & $\begin{array}{l}\text { Civil Affairs and } \\
\text { Community Governance }\end{array}$ & $\begin{array}{l}\text { Senior Governor, District Government, Shenzhen, } \\
\text { Guangdong, China. }\end{array}$ \\
\hline 2 & Dr BB & $\begin{array}{l}\text { Urban and } \\
\text { Community Planning }\end{array}$ & $\begin{array}{l}\text { Professor, The University of XX, Guangzhou, } \\
\text { Guangdong, China. }\end{array}$ \\
\hline 3 & Ms CC & Urban Planning and Design & $\begin{array}{l}\text { Senior Planner, a professional urban planning and } \\
\text { design Institute, Guangzhou, Guangdong, China. }\end{array}$ \\
\hline 4 & Dr DD & $\begin{array}{l}\text { Public Space Management } \\
\text { and Policy }\end{array}$ & Professor, The University of YY, UK. \\
\hline 5 & Dr EE & $\begin{array}{l}\text { Planning Methodology } \\
\text { and Technology }\end{array}$ & $\begin{array}{l}\text { Senior Researcher, The University of ZZ, } \\
\text { Shanghai, China. }\end{array}$ \\
\hline 6 & Ms FF & $\begin{array}{l}\text { Urban Renewal and } \\
\text { Public Participation }\end{array}$ & $\begin{array}{l}\text { Project Manager, a renowned NGO, Shenzhen, } \\
\text { Guangdong, China. }\end{array}$ \\
\hline 7 & Dr GG & $\begin{array}{l}\text { Green Technology and } \\
\text { Environmental Regulation }\end{array}$ & Professor, The University of UU, Beijing, China. \\
\hline 8 & Dr HH & Elderly Friendly Community & $\begin{array}{l}\text { Director of A professional planning and design institute, } \\
\text { Shanghai, China. }\end{array}$ \\
\hline 9 & Dr II & $\begin{array}{l}\text { Neighborhood and } \\
\text { Participatory Planning }\end{array}$ & $\begin{array}{l}\text { Professor, The University of VV, Guangzhou, } \\
\text { Guangdong, China. }\end{array}$ \\
\hline 10 & Mr JJ & Community Governance & Director of XX Community, Chengdu, China. \\
\hline 11 & Dr KK & Urban Planning & $\begin{array}{l}\text { Senior Urban Planner, Urban Planning and Design } \\
\text { Institute of XX city, Jiangsu, China. }\end{array}$ \\
\hline 12 & Dr LL & $\begin{array}{l}\text { Urban Design and residential } \\
\text { area planning }\end{array}$ & $\begin{array}{l}\text { Former chief planner of Urban Planning and Design } \\
\text { institute, XX city, Hubei, China }\end{array}$ \\
\hline
\end{tabular}

\section{Results and Discussion}

\subsection{Common Characteristics of Neighborhood Planning in Other Countries}

Through the extensive analysis of various sources, nine common characteristics shared by neighborhood planning practices in the UK, the US, Canada and Taiwan were identified, especially the neighborhood plan documents. Basically, the type of neighborhood plan may vary from countries to adapt to the specific context of neighborhood governance. The four selected cases in these corresponding countries for comparative study are Globeville Neighborhood Planning (US), Alnwick and Denwick Neighborhood Planning (UK), Maillardville Neighborhood Planning (Canada) and Yi Lan Community empowerment Project (Taiwan). The comparative study is based on the four institutional aspects in neighborhood planning to achieve local sustainability highlighted in Section 2.2. Each of the institutional aspects are further broken down into several points as shown in Table 4. Through the comparative study, the key nine common characteristics were identified and shown in Table 4. 
Table 4. Different aspects for comparison and identified common characteristics of neighborhood planning practice in four countries.

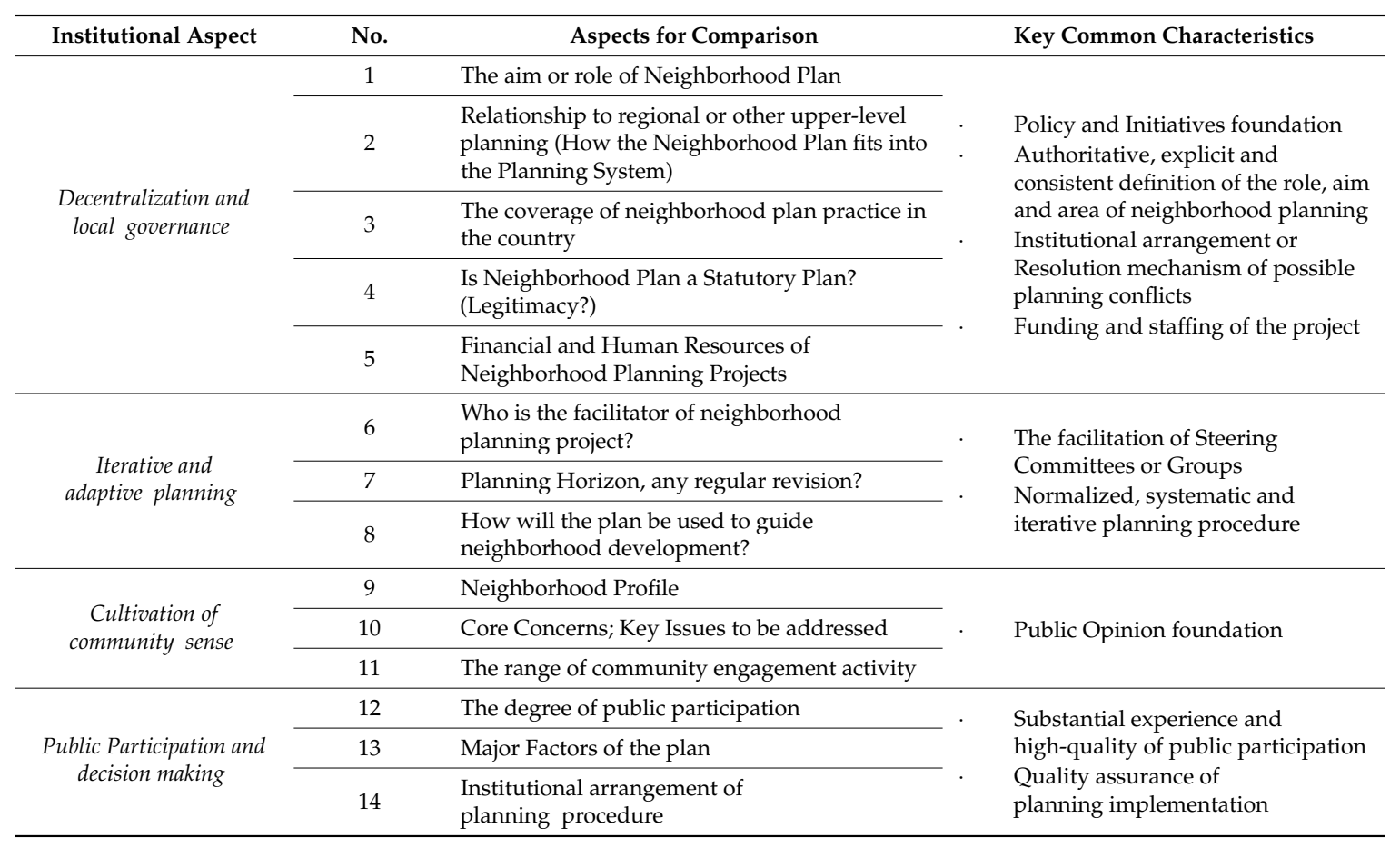

\subsection{Barriers to Neighborhood Planning Development in China}

In reference to the comparative study above, the authors further transform the common characters into nine preliminary barriers that possibly hinder the development of neighborhood planning in China. Then the twelve experts were interviewed to validate the applicability of these nine barriers in the context of China. The experts were asked to indicate whether he or she agreed with each corresponding barrier. Finally, the results from eight out of twelve experts were regarded as valid ones. These eight were chosen as they both had been involved in housing planning, neighborhood governance, community revitalization projects in China and were able to give a valid mark on each statement during the interview.

Table 5. The Overall Consent Rate of the Proposed Barriers.

\begin{tabular}{clc}
\hline No. & \multicolumn{1}{c}{ Specific Barrier } & Total Consent Rate \\
\hline 1 & Weak sense of comunity & $87.5 \%$ \\
2 & Lack of national policy foundation and explicit official definition & $75 \%$ \\
3 & Unclear accountable body of neighborhood planning project & $75 \%$ \\
4 & Lack of institutional arrangement or Resolution mechanism of planning conflicts & $50 \%$ \\
5 & Inadequate experience, degree and platform of public participation & $100 \%$ \\
6 & Inadequate financial and human resource support & $75 \%$ \\
7 & Lack of the facilitation of Steering Committee & $50 \%$ \\
8 & Lack of institution and mechanism for planning implementation and evaluation & $75 \%$ \\
9 & Planning procedure is not normalized, systematic and iterative & $75 \%$ \\
Other barriers suggested by the experts: & \\
S1 & Inadequate updated laws and regulations to define the authority and liability of & \\
S2 & neighborhood public space management & \\
\hline
\end{tabular}

According to the results of the expert validation, two items were eliminated due to their low consent rate since $70 \%$ agreement is considered necessary in interpreting percentage agreement [69] whereas two extra items were added based on the experts' supplements (Table 5). It was found that 
the experts agreed on most of the barriers and provided further elaborations which engender a more holistic perspective.

The finalized nine barriers were categorized into three major areas: Insufficient policy design and legal support; Inappropriate local governance and planning context; and Weak sense of community and participation in planning. These three areas are closely associated with the four institutional aspects of how neighborhood planning relates to local sustainability in Section 2.2. Some of these identified barriers had also been demonstrated in previous research for hindering the sustainable urban development in China [51]. Each barrier is further elaborated on as follows:

\subsubsection{Insufficient Policy Design and Legal Support}

\section{- Lack of national policy foundation and explicit official definition}

Decentralization through the enactment of national or provincial policies was the common characteristic of the US, the UK, Canada and Taiwan and neighborhood planning acted as one of the typical methods of decentralization. Comparatively, it was not until June 2017 that neighborhood planning has been firstly and formally included in national policy and guidelines in China. The central government has issued this updated policy guideline to 'Enhancing and improving urban-rural neighborhood governance.' However, 'Organizing and making neighborhood planning in pilot cases' were only mentioned in one paragraph under the subheading of 'Optimizing the neighborhood resource allocation' [70]. Yu and Cai [71] stated that neighborhood planning has not drawn as sufficient attention from senior policy makers as urban planning has. Prior to the recent policy, the only relevant plan was issued by the National Ministry of Civil Affairs as an initiative policy to promote constructing a community service system. However, according to one of the interviewees who is the local governor of the Department of Civil Affairs in Shenzhen, practical actions are very limited at municipal level and much less the further measures and significant achievement at lower level by following this national advocacy. It is argued that neighborhood planning and building cannot be efficiently facilitated without major involved departments' and stakeholders' participation.

Besides, as there is a lack of explicit and authoritative definition about the role and aim of 'neighborhood planning' in China's national guidelines, many projects are conducted on a case by case basis rather than following predetermined nationwide practices. In comparison, there is an authoritative, explicit and consistent definition of the role, aim and scope of neighborhood planning in the other four countries. The role of neighborhood planning is seen as complementary to local planning and is coordinated with municipal-level planning to achieve a city's developmental goal without neglecting individual neighborhood interests.

- Inadequate updated laws and regulations that define the authority and liability of neighborhood management

As a result of immense urbanization and institutional reform, the community profiles have already been comprehensively transformed. However, the legal system of urban community governance has not been well established and updated. Under these circumstances, very few laws and regulations have been formulated to clearly define the authority and liability of neighborhood public space management, which, otherwise, could be the baseline for community governance (Expert 1 and 2). Besides, very few local policies had been issued to provide a mechanism for ordinary neighborhood members participating in neighborhood planning and environmental management [72,73]. Neighborhood planning cannot be effectively practiced within a fuzzy and ambiguous legal and governance system where mediation and arbitration is not always constructive. Thus, the lack of a clearly defined role for management power and responsibility concerning public spatial issues and property rights is one of the systematic barriers to initiating neighborhood planning. 
- Unclear accountable body of neighborhood planning project

In all four countries, a core facilitator of the project, a steering group or a responsible team bears the responsibility to lead, organize and monitor the process of a neighborhood planning project. Usually, this team contains different stakeholders to engage affected communities. But such responsible and accountable body was not clearly designated in China. In fact, the Land Use and Urban Planning Bureau, Department of Civil Affairs, Street Office, Residents' Committee are all involved in different stages of neighborhood planning processes in China. However, the absence of a main accountable leader makes the allocation of authority and responsibility to the corresponding departments unclear (Expert 9). Therefore, it is common that different bodies 'pass the buck,' especially in the planning implementation phases. Consequently, the facilitation of planning procedure has been hindered.

\subsubsection{Inappropriate Local Governance and Planning Context}

\section{- Highly bureaucratic residents' committee of the community}

As the major governance institution of neighborhood in China, the Community Residents' Committee (CRC) and its efforts play a critical role in neighborhood planning projects. In principle, CRC is officially defined as an autonomous organization of local residents. However, this grassroots organization has become highly bureaucratized and been largely accountable to street office since it was firstly established and has managed to rule the community in the 'Planned Economy Era.' This situation is against the principle of 'planning for the people.'

The municipal governance hierarchy, as shown in Figure 2, is a three-level vertical system. There has been evidence of frequent or even inevitable intervention of Street Office, which is the agency and lowest level of urban local government, with community autonomy in terms of top-down (Street office to Community Residents' Committee) financial allocation and human resource nomination authority, etc. (Expert 1). In fact, the fiscal appropriation from street office is legally allowed and the main financial source of CRC. Therefore, CRC institutionally became to be an extension of local government into neighborhoods and accountable to Street Office rather than the most important stakeholder-residents, to a large extent. These actual arrangements were accused of damaging the degree of autonomy and work against the official implication of 'community' as a basic autonomous unit. Since neighborhood planning should be collaborative and interactive, involving 'bottoms-up' participation, the lower degree of autonomy is a fundamental barrier to nurturing residents' concerns about their own interests and facilitating neighborhood planning.

\section{- Inadequate financial and human resource support}

In the other four countries, individual funding is often allocated from the local town council or municipal government as well as extra funding obtained from the upper-level government. Regarding the staffing of the project, the project team members include representatives from different stakeholders ranging from the government, community residents, developers, academics, professionals, to NGOs, etc.

However, neighborhood planning lacks regular financial and human resource support in China. Unlike those foreign countries, financial support for neighborhoods planning is limited and policy-oriented. There is no regular funding for neighborhood planning so far and all available funding were managed by the department of Civil Affairs which is not responsible for planning project (Expert 1). Regarding human resource, the lack of professionals who are both proficient in urban planning and community studies presents another key challenge. Chinese planning practitioners have insufficient experience and knowledge related to neighborhood planning [15]. The current professional urban planners who were trained as urban engineers are not competent to deal with new and integrated social-dimension problems in the community. This problem has been aggravated by the 
absence of Neighborhood Planning courses in current planning training schemes in higher education institutions (Expert 2).

- Lack of institutions and mechanisms for planning implementation and evaluation

In the other four countries, the adopted plans are gradually implemented under a political mechanism, such as becoming a part of a statutory plan through referendum in the UK and adoption by the city council in the US and Canada. The National Development Council of Taiwan also regularly heads different level of departments to monitor and evaluate the project performance as quality assurance.

In comparison, little research has focused on the implementation and evaluation of neighborhood planning in China. Thus, the adaptive neighborhood planning theories in China were scarce [74], which further led to the absence of theoretical foundation for delivering planning implementation and evaluation. In practice, government is currently concerned more with policy rather than its implementation and evaluation. For instance, although the municipal Department of Civil Affairs of Shenzhen issued official guidelines on neighborhood development, very few local neighborhoods checked on plan implementation or evaluated impact (Expert 1). Without substantial implementation and management, how a planning policy initiative work effectively is questionable.

\subsubsection{Weak Sense of Community and Participation in Planning}

\section{- Weak collective sense of community}

Unlike relatively stronger sense of communities in other four countries, the community sense was still yet to be cultivated in transitional China. Previously, the maintenance of 'community sense' passively relied on the 'top-down' political administration. This situation began to change in the late 1980s, during which time market-oriented economic reforms were implemented and the neighborhoods' demographical profiles began to change. A growing number of residents chose to move out and purchase new commodity flats in the market. Thus, neighborhood clusters became a mixture of old work units and newly developed commodity and gated communities. However, as the old danwei-based community sense has gradually dissolved, a new sense of community in 'commodity houses' has not yet built up (Experts 2 and 9). To date, the residents from both the old danwei and the new commodity community system had not yet got involved with public issues nor being active in taking collective action.

\section{- Inadequate experience, degree and platform of public participation}

It is believed that public participation mode is imperative or even pre-requisite for successful neighborhood planning. Thus, the sense, degree and platform of public participation determine the effectiveness of neighborhood planning in helping resolve neighborhood problems in a collaborative way. In reviewing the history of public participation, it is apparent that the three Western countries have a relatively longer history of public engagement with local governance, while Taiwan has had a shorter period but still performs well when it comes to motivating grassroots' participation.

However, due to historical and social ideological reasons, these three elements have not been substantially and constructively improved in previous planning practices (Expert 2). Liu et al. [51] stated that there is still a lack of broad participation on local level and by civil society although both top-down and bottom-up initiatives have been tested. The effectiveness of public participation in the local planning process is still doubtful. Expert 12 emphasized the ineffective authority's feedback after public consultation. According to her past experience of organizing public consultation on urban planning in City A, residents felt discouraged and would not attend again since their thoughts and comments on plan during the previous consultation did not receive effective and timely feedback 
from the authorities. This is one of the critical reasons the participation rate is fairly low in China. She advocates a more transparent and efficient participating mechanism to address this problem.

\section{- Planning procedure is not normalized, systematic and iterative}

Neighborhood planning refers to both the simple process of collecting residents' feedback and elaborating on and addressing social problems in a professional way (Expert 9). This emphasizes that planning procedures should not be a one-stop process but iterative, systematic and normalized.

Although many different forms, methods and participants are involved in neighborhood planning, normalized systematic and iterative procedures are the three common features found in the successful practices of these four countries. Therefore, a wide range of quality services at the neighborhood level and a more responsive, interactive planning procedure are provided for residents to express their concerns and needs. Institutionally, several rounds of proposal appraisal within the iterative planning process also guaranteed that the drafted plan meet the condition of core principles or frameworks.

By contrast, the existing Neighborhood planning practices reflected that both the public and authority concern more about whether planning outcomes achieve the pre-set goal rather than procedure is appropriate in China. This inappropriate situation was associated with both the conventional outcome-oriented value and deficiency of current urban planning system. It also led to the failure in tracking the residents' long-term feedback on planning implementation (Expert 3).

\section{Policy Implications and Recommendations}

Globally, it is important to note that neighborhood planning was never an independent movement or scheme, despite the social-political context in countries worldwide. Politically, it was utilized as a policy tool to deal with the interplay between decentralization and localism in corresponding countries. But, in spite of diverse objectives across the world, it is commonly agreed upon that a participatory method with local input into the planning lifecycle is fundamental. It suggests that the neighborhood planning could be practiced in different forms, such as neighborhood revitalization or community development etc., throughout China due to its diverse local context. Interestingly, the special local context, especially the existence of $\mathrm{CRC}$, may provide a special chance for developing their own form of neighborhood planning in China. Regarding the global trend and the China context, as well as barriers identified above, several recommendations that could help facilitate neighborhood planning practices in China are given below.

Firstly, exploring and developing explicit national policies and initiatives regarding neighborhood planning would be helpful. As discussed in 5.2.1., the Central Government has gradually paid more attention to neighborhood planning and a national guideline has been issued as well as completed a number of pilot projects in major cities. Given the national strategy and the aspiration of residents are basically consistent, deepening the general and abstract national guidelines to provide an authoritative and explicit policy foundation for neighborhood planning would be appropriate. Based on proposed national policies, the involved departments, including the Urban and Rural Housing Ministry, Civil Affairs Ministry and Department of Finance, etc., could foster better coordination and interdepartmental reform in forming a comprehensive framework for nationwide neighborhood planning practices and management. As a result, legal accountability would be ensured.

Secondly, substantial reform of local governance and the planning education system is urgently needed. Since the setup of grassroots governance in the planned economy era, the Community Residents' Committee (CRC) has adopted bureaucratic administration procedures. This problem has recently become even more controversial, as its role and authority has been enhanced due to the national policy of 'Community Building.' To be in line with the official role of CRC as the resident autonomy organization, substantial institutional reform is needed to remove local institutional barriers for decentralization of decision making and to legitimate public participation. Special attention could be paid to the Central Government's poor results in enhancing local preservation and environmental 
protection, as stated by Ding [75]. To address the problem of inadequate professionals delivering the projects, community planning could be added as part of the current higher education curriculum in planning as a supplement to professional training.

Lastly, nurturing a stronger sense of community through diversifying the forms and avenues of public participation could be encouraged. For planning participation, more interactive and participatory channels, such as workshops, open forums, live discussion, competition, etc., could be adopted to facilitate effective planning participation at different phases of the project. The administrative area of one community is a suitable scale within which potential participators can be engaged by the powerful residents' committee. For community issues, normalized, scientific and deliberate community institutions could be established under the leadership of CRC. This would provide a regular channel for residents' representatives to make direct contributions to the discussion and resolution of community issues. Of course, public education, such as law and rules of order lecture (expert 1), is important for raising people's awareness and their capability to provide useful opinions. Therefore, the sense of community and collective capacity to resolve public issues voluntarily would be cultivated and enhanced. These would be beneficial to nurturing a stronger sense of community and laying a solid ideological foundation for practicing neighborhood planning.

\section{Conclusions}

This paper highlights the important institutional elements of neighborhood planning in contributing to sustainable development and identifies the challenges and opportunities of facilitating neighborhood planning in China. As a global issue, many local sustainability challenges at neighborhood level emerged due to the rapid urbanization in China. The exclusive transition of the 'Danwei' system and 'Community Building' makes the neighborhood profile even more complex and further challenges sustainable neighborhood development. As its rising effects in achieving sustainable development throughout the world, neighborhood planning increasingly drew both academics' and governments' attention in urban China. Thus, this paper aims to further ascertain the challenges and opportunities of its potential development. Particularly, the importance and priority of studying institutional barriers was highlighted by the prominence of institutional elements in neighborhood governance, urban planning and sustainable development in China.

Firstly, nine key and common characteristics reflected in neighborhood planning were identified through a comparative study of different countries' planning practices based on the theoretical relationship between neighborhood planning and sustainability. Since it has been argued that due to the different social-political context in transitional China, these characteristics may not be entirely applicable in illustrating the circumstance of China. Therefore, through literature review, this paper secondly identifies a list of major barriers that could hinder the development of effective neighborhood planning practices in China and nine barriers were consequently ascertained. Lastly, the barriers have been further validated and investigated through interviews with experts.

The validated three major barriers stem from lack of support from national policies and local governance, unclear legislation regarding community public management, as well as inadequate public participation based on a weak sense of community. This result turned out to be closely associated with the theoretical relationship between neighborhood planning and local sustainability in sector 2.2., which also implied the interference effect of these barriers on sustainable neighborhood development in China. Recommendations for tackling these barriers and for developing and implementing neighborhood planning are provided. The results of this study could provide valuable insights for urban planners and government decision makers. The findings could aid them in further exploring how neighborhood planning practices in China could be better implemented, with the end goal of achieving sustainable neighborhoods and better quality of life.

In summary, this paper adds to the literature on neighborhood planning both from a global and Chinese perspective. Particularly, it highlighted the local adaptability of neighborhood planning by ascertaining the differences of institutional context between China and other advanced countries. It also 
further demonstrates challenges and opportunities for facilitating neighborhood planning in China and raises several questions that should be further investigated: What are the underlying factors involved in cultivating sustainable neighborhoods in China and what are the specific and unique sustainability indicators? What is the proper operational mechanism for neighborhood planning that fits into both the planning system and local social-political context? Constructing a comprehensive sustainability framework for neighborhood planning and helping cultivate more sustainable neighborhoods in China could be feasible if all these potential research questions were resolved.

Acknowledgments: This study is supported by a research grant provided by the Hong Kong Polytechnic University. The authors gratefully acknowledge all those who contributed to the interviews. Funds for covering the costs to publish in open access is provided by the University.

Author Contributions: Qi Zhang and Esther Yung developed the theoretical formalism; Qi Zhang conducted the desktop reviews and expert interviews, drafted the manuscript as well as designed the figures; Esther Yung substantively optimized the structure and revised some arguments of the manuscript; Edwin Chan assisted on the outline plan of work, expert interviews and provided feedback on the article; Esther Yung and Edwin Chan supervised the project.

Conflicts of Interest: The authors declare no conflict of interest.

\section{References}

1. United Nations. Agenda 21: The Rio Declaration on Environment and Development. Available online: https://sustainabledevelopment.un.org/outcomedocuments/agenda21 (accessed on 7 December 2017).

2. Camagni, R. On the concept of territorial competitiveness: Sound or misleading? Urban Stud. 2002, 39, 2395-2411. [CrossRef]

3. Thabrew, L.; Wiek, A.; Ries, R. Environmental decision making in multi-stakeholder contexts: Applicability of life cycle thinking in development planning and implementation. J. Clean. Prod. 2009, 17, 67-76. [CrossRef]

4. Rauscher, R.C.; Momtaz, S. Conclusions and directions for sustainable neighborhood planning. In Sustainable Neighborhoods of Australia; Springer International Publishing: Cham, Switzerland, 2015; pp. 193-201.

5. United Nations Commission on Sustainable Development (UNCSD). Report of the World Summit on Sustainable Development; United Nations Publication: Johannesburg, South Africa, 26 August-4 September 2002.

6. Satterthwaite, D. Successful, safe and sustainable cities: Towards a New Urban Agenda. Commonw. J. Local Gov. 2017, 3-18. [CrossRef]

7. Choguill, C.L. Developing sustainable neighborhoods. Habitat Int. 2008, 32, 41-48. [CrossRef]

8. Rohe, W.M. From local to global: One hundred years of neighborhood planning. J. Am. Plan. Assoc. 2009, 75, 209-230. [CrossRef]

9. Boyoko, C.; Cooper, R.; Davey, C.; Wootton, A. Addressing sustainability early in the urban design process. Manag. Environ. Qual. Int. J. 2006, 17, 689-706. [CrossRef]

10. Sharifi, A.; Murayama, A. A critical review of seven selected neighborhood sustainability assessment tools. Environ. Impact Assess. Rev. 2013, 38, 73-87. [CrossRef]

11. Valentin, A.; Spangenberg, J.H. A guide to community sustainability indicators. Environ. Impact Assess. Rev. 2000, 20, 381-392. [CrossRef]

12. Friedmann, J.; Fang, C. Towards Sustainable Neighborhoods: The Role of Social Planning in China-A Case Study of Ningbo, Zhejiang Province. City Plan. Rev. 2011, 1, 30-40.

13. Wang, Y.; Jiang, P.; Xia, T. Inspiration from pilot community planning of Wulian in Longgang district of Shenzhen. City Plan. Rev. 2009, 4, 17.

14. Li, J.; Fu, Y.; Li, J.; Guo, L. Some thinking on Sustainability of residential district Planning. Urban Plan. Forum 2008, 90-95.

15. Shi, Q.; Yu, T.; Zuo, J.; Lai, X. Challenges of developing sustainable neighborhoods in China. J. Clean. Prod. 2016, 135, 972-983. [CrossRef]

16. Wei, Y.H.D. Restructuring for growth in urban China: Transitional institutions, urban development, and spatial transformation. Habitat Int. 2012, 36, 396-405. [CrossRef]

17. Zhu, Y.; Breitung, W.; Li, S. The Changing Meaning of Neighborhood Attachment in Chinese Commodity Housing Estates: Evidence from Guangzhou. Urban Stud. 2012, 49, 24-39. [CrossRef] 
18. Li, H.; Wei, Y.D.; Liao, F.H.; Huang, Z. Administrative hierarchy and urban land expansion in transitional China. Appl. Geogr. 2015, 56, 177-186. [CrossRef]

19. Garde, A. Sustainable by design: Insights from US LEED-ND pilot projects. J. Am. Plan. Assoc. 2009, 75, 424-440. [CrossRef]

20. Jacobs, J. The Death and Life of Great American Cities; Random House: New York, NY, USA, 1961.

21. Berardi, U. Sustainability assessment of urban communities through rating systems. Environ. Dev. Sustain. 2013, 15, 1573-1591. [CrossRef]

22. Spangenberg, J.H.; Pfahl, S.; Deller, K. Towards indicators for institutional sustainability: Lessons from an analysis of Agenda 21. Ecol. Indic. 2002, 2, 61-77. [CrossRef]

23. Perry, C.A. City planning for neighborhood life. Soc. Forces 1929, 8, 98-100. [CrossRef]

24. Wellman, B.; Leighton, B. Networks, neighborhoods, and communities: Approaches to the study of the community question. Urban Aff. Q. 1979, 14, 363-390. [CrossRef]

25. Bostic, R.W.; Martin, R.W. Black home-owners as a gentrifying force? Neighborhood dynamics in the context of minority home-ownership. Urban Stud. 2003, 40, 2427-2449. [CrossRef]

26. Chaskin, R.J.; Garg, S. The issue of governance in neighborhood-based initiatives. Urban Aff. Rev. 1997, 32, 631-661. [CrossRef]

27. Park, Y.; Rogers, G.O. Neighborhood planning theory, guidelines, and research: Can area, population, and boundary guide conceptual framing? J. Plan. Lit. 2015, 30, 18-36. [CrossRef]

28. Li, S.M.; Hou, Q.; Chen, S.; Zhou, C. Work, home, and market: The social transformation of housing space in Guangzhou, China. Urban Geogr. 2010, 31, 434-452. [CrossRef]

29. Bradley, Q. The Political Identities of Neighborhood Planning in England. Space Polity 2015, 19, 97-109. [CrossRef]

30. How to Prepare a Neighborhood Plan. Available online: https://planninghelp.cpre.org.uk/improve-whereyou-live/shape-your-local-area/neighborhood-plans/how-to-prepare-a-neighborhood-plan (accessed on 30 January 2018).

31. Sirianni, C. Neighborhood planning as collaborative democratic design: The case of Seattle. J. Am. Plan. Assoc. 2007, 73, 373-387. [CrossRef]

32. Stoney, C.; Elgersma, S. Neighborhood Planning through Community Engagement: The Implications for Place Based Governance and Outcomes. In Proceedings of the Canadian Political Science Association, Saskatoon, Canada, May/June 2007. Available online: https://carleton.ca/cure/wp-content/uploads/ Stoney_Elgersma_2007.pdf (accessed on 10 July 2017).

33. Evans, B.; Joas, M.; Sundback, S.; Theobald, K. Governing Sustainable Cities; Routledge: London, UK, 2005.

34. Awortwi, N. An unbreakable path? A comparative study of decentralization and local government development trajectories in Ghana and Uganda. Int. Rev. Adm. Sci. 2011, 77, 347-377. [CrossRef]

35. Kakumba, U. Local government citizen participation and rural development: Reflections on Uganda's decentralization system. Int. Rev. Adm. Sci. 2010, 76, 171-186. [CrossRef]

36. Bennett, L. Using empowerment and social inclusion for pro-poor growth: A theory of social change. In Working Draft of Background Paper for the Social Development Strategy Paper; World Bank: Washington, DC, USA, 2002.

37. Tan, R.; Zhou, T. Decentralization in a centralized system: Project-based governance for land-related public goods provision in China. Land Use Policy 2015, 47, 262-272. [CrossRef]

38. Barry, J. Communicating a Politics of Sustainable Development; Eolss Publishers: Oxford, UK, 2003.

39. Yung, E.H.K.; Chan, E.H.W. Critical social sustainability factors in urban conservation: The case of the central police station compound in Hong Kong. Facilities 2012, 30, 396-416. [CrossRef]

40. Lang, D.J.; Wiek, A.; Bergmann, M.; Stauffacher, M.; Martens, P.; Moll, P.; Swilling, M.; Thomas, C.J. Transdisciplinary research in sustainability science: Practice, principles, and challenges. Sustain. Sci. 2012, 7, 25-43. [CrossRef]

41. Fraser, E.D.; Dougill, A.J.; Mabee, W.E.; Reed, M.; McAlpine, P. Bottom up and top down: Analysis of participatory processes for sustainability indicator identification as a pathway to community empowerment and sustainable environmental management. J. Environ. Manag. 2006, 78, 114-127. [CrossRef] [PubMed]

42. Drilling, M.; Schnur, O. Nachhaltigkeit in der Quartiersentwicklung-einführendeAnmerkungen; VS Verlag für Sozialwissenschaften: Wiesbaden, Germany, 2012; pp. 11-41. 
43. Talen, E. Sprawl retrofit: Sustainable urban form in unsustainable places. Environ. Plan. B Plan. Des. 2011, 38, 952-978. [CrossRef]

44. Bess, K.D.; Fisher, A.T.; Sonn, C.C.; Bishop, B.J. Introduction. In Psychological Sense of Community: Research, Applications and Implications; Fisher, A.T., Sonn, C.C., Bishop, B.J., Eds.; Kluwer Academic/Plenum Publishers: New York, NY, USA, 2002; p. 6.

45. Farrell, S.; Aubry, T.; Coulombe, D. Neighborhoods and neighbours. Do they contribute to personal well-being? J. Community Psychol. 2004, 32, 9-25. [CrossRef]

46. Prezza, M.; Constantini, S. Sense of community and life satisfaction: Investigation in three different territorial contexts. J. Community Appl. Soc. Psychol. 1998, 8, 181-194. [CrossRef]

47. Kwakkel, J.H.; Van der Pas, J.W.G.M. Evaluation of infrastructure planning approaches: An analogy with medicine. Futures 2011, 43, 934-946. [CrossRef]

48. McDaniel, R.R.; Driebe, D.J. Uncertainty and Surprise in Complex Systems; Springer: Berlin/Heidelberg, Germany; New York, NY, USA, 2005.

49. Marique, A.F.; Reiter, S. Towards more sustainable neighborhoods: Are good practices reproducible and extensible? A review of a few existing sustainable neighborhoods. In Proceedings of the 27th Conference on Passive and Low Energy Architecture, Louvain-la-Neuve, Belgium, 13-15 July 2011.

50. National Development and Reform Commission. National Report on Sustainable Development Report. Available online: http:/ / www.china-un.org/eng/zt/sdreng/P020120608816970051133.pdf (accessed on 15 December 2017).

51. Liu, H.; Zhou, G.; Wennersten, R.; Frostell, B. Analysis of sustainable urban development approaches in China. Habitat Int. 2014, 41, 24-32. [CrossRef]

52. Huang, L.; Luo, Y. Community Planning and the Local Approach in the Perspective of Social Governance Innovation-A Case Study of Shiyou Road, Yuzhong District of Chongqing. J. Hum. Settl. West China 2014, 5, 5.

53. Zhao, W.; Zhao, M. From Residential Area Planning to Community Planning. Urban Plan. Forum 2002, 06, 68-71.

54. Sun, L.; Yung, E.H.; Chan, E.H.; Zhu, D. Issues of NIMBY conflict management from the perspective of stakeholders: A case study in Shanghai. Habitat Int. 2016, 53, 133-141. [CrossRef]

55. Xu, M.Y.; Tao, D.K. Exploring and Thinking Over the Public Participation in Urban Plan Formulation in The New Period: A Case Study of Nanjing Master Plan Revision. City Plan. Rev. 2012, 2, $73-81$.

56. Walder, A. The informal dimension of enterprise financial reforms. China's Econ. Looks Year 2000 1986, 1, 630-645.

57. Ma, W.; Li, L.C. Community governance reform in urban China: A case study of the Yantian model in Shenzhen. J. Comp. Asian Dev. 2012, 11, 224-247. [CrossRef]

58. Xia, J.Z. An empirical study on self-governing organizations in new-style urban communities. Soc. Sci. China 2008, 29, 171-180. [CrossRef]

59. $\mathrm{Xu}, \mathrm{F}$. Gated communities and migrant enclaves: The conundrum for building 'harmonious community/shequ'. J. Contemp. China 2008, 17, 633-651. [CrossRef]

60. Derleth, J.; Koldyk, D. The Shequ Experiment: Grassroots political reform in urban China. J. Contemp. China 2004, 13, 747-777. [CrossRef]

61. Gu, C.; Hu, L.; Guo, J.; Cook, I.G. China's urban planning in transition. Proc. Inst. Civ. Eng. Urban Des. Plan. 2014, 167, 221-236. [CrossRef]

62. Bogner, A.; Menz, W. The theory-generating expert interview: Epistemological interest, forms of knowledge, interaction. In Interviewing Experts; Bogner, A., Littig, B., Menz, W., Eds.; Palgrave Macmillan: London, UK, 2009; pp. 43-80.

63. Bird, K. Neighborhood Sustainability Assessment: Connecting Impact with Policy Intent. 2015. Available online: http:/ / rem-main.rem.sfu.ca/theses/BirdKiri_2015_MRM620.pdf (accessed on 18 October 2017).

64. Planning Practice Guidance. Available online: http://planningguidance.communities.gov.uk/blog/ guidance/neighborhood-planning/ (accessed on 15 December 2017).

65. Seattle Department of Neighborhoods. 2016. Available online: https://www.seattle.gov/neighborhoods / programs-and-services/neighborhood-planning (accessed on 15 December 2017).

66. A Guide for Developing Neighborhood Plans. Manitoba Intergovernmental Affairs and the City of Winnipeg's Planning, Property and Development Department -Planning and Land Use Division. 2002. Available online: http:/ / www.winnipeg.ca/ppd/pdf_files/Nhbd_guide.pdf (accessed on 15 December 2017). 
67. Community Empowerment Network, Taipei. Available online: http://en.community-taipei.tw/ introduction.jsp (accessed on 15 December 2017).

68. Worldometers. Available online: http://www.worldometers.info/population/ (accessed on 15 December 2017).

69. House, A.E.; House, B.J.; Campbell, M.B. Measures of interobserver agreement: Calculation formulas and distribution effects. J. Psychopathol. Behav. Assess. 1981, 3, 37-57. [CrossRef]

70. Xinhua News Agency. CPC Central Committee and Central Government's Advice on Enhancing and Improving Urban-Rural Neighborhood Governance. Available online: http:/ / news.xinhuanet.com/politics/ 2017-06/12/c_1121130511.htm (accessed on 1 December 2017).

71. Yu, K.H.; Cai, H. A research on community planning system reconstruction and new mechanism in China from the perspective of low-carbon. Ecol. Econ. 2012, 7, 183-188.

72. Zhang, X.; Shen, G.Q.; Feng, J.; Wu, Y. Delivering a low-carbon community in China: Technology vs. strategy. Habitat Int. 2013, 37, 130-137. [CrossRef]

73. Chen, M.; Qian, X.; Zhang, L. Public participation in environmental management in China: Status quo and mode innovation. Environ. Manag. 2015, 55, 523-535. [CrossRef] [PubMed]

74. Liu, J.Y.; Deng, X.Y. Community planning based on socio-spatial production: Explorations in "new qinghe experiment". City Plan. Rev. 2016, 11, 9-14.

75. Ding, C. Policy and praxis of land acquisition in China. Land Use Policy 2007, 24, 1-13. [CrossRef]

(C) 2018 by the authors. Licensee MDPI, Basel, Switzerland. This article is an open access article distributed under the terms and conditions of the Creative Commons Attribution (CC BY) license (http://creativecommons.org/licenses/by/4.0/). 